\title{
The Influence of Work Motivation and Compensation on Employee Performance in PT Delami Brands Kharisma Busana Surabaya
}

\author{
Nur Laili Safitri*, R. Agus Baktiono, Elok Damayanti, \& I Gede Arimbawa \\ Faculty of Economics and Business, Narotama University, Surabaya, Indonesia
}

\begin{abstract}
This study aims to determine the effect of work motivation and compensation on the performance of PT. Delami Brands Kharisma Busana Surabaya. This study used a quantitative approach and data collection through questionnaires and observations. With a population of 76 respondents. Analysis of the data used the validity test, reliability test, classic assumption test, and multiple linear analysis test. The results showed that the effect of work motivation and compensation on the performance of PT. Delami Brands Khasrisma Busana Surabaya showed positive and significant results. The F test results are 70,878> F table $=2,92$ simultaneously. Partially work motivation of 8.433>t table 1.993 has a significant effect on employee performance, compensation of $4.564>1.993$ has a significant effect on the performance of employees of PT. Delami Brands Kharisma Busana Surabaya.
\end{abstract}

Keywords: Work motivation, compensation; employee performance.

\section{Introduction}

PT. Delami Brands Kharisma Busana was founded in 1979 by Mr. Johanes Farial, with the name PT.Delami Garment Industries is a company engaged in the fashion and manufacturing industries. by producing men's trousers for the domestic market. This smart move saw the expansion of PT. Delami is one of the leading garment manufacturers in Indonesia. In 1987, PT. Delami continued to expand and began launching products to the United States. In 1994, PT. Delami won production, marketing and distribution licenses for the Indonesian market. The position and approval of the company in the domestic market is approved by introducing a collection of women's clothing. In 2000, PT. Delami received prestigious recognition of ISO 9001 international quality standardization. That same year saw the company become a licensee of Jeans for Singapore, Malaysia and Brunei Darussalam. Increasing production in the world of fashion and retail PT. Delami Garment Industry has changed the name of its company to PT. Delami Brands Kharisma Busana in 2016 and has superior brand products such as: Executive, Wood, Wrangler, Et-Cetera, Colorbox, Lee, Jocky, Tira, choya. The products produced also include retail clothing such as apparel, such as clothes, pants, jackets, and so on. The products are mostly exported and are mostly marketed domestically, including Surabaya.

To overcome the increasing business competition, it is also marked by the growth and development of industries in Indonesia. Competition between companies both in the retail and service sectors is getting tougher, all companies that move as much as possible to attract interest The role of human resources in an important organization because it is the main driver of the smooth running of the organization, so that it can compete in national, regional and international markets and encourage to achieve company goals, especially in companies engaged in retail. With the victory of the sales target for each employee to get loyalty or bonuses, this special program arises power competition against fellow workers or partners that have been determined by the company. In an organization there are factors that influence employee performance are motivation and compensation. Motivation itself is an internal condition that encourages us to encourage, encourage us to achieve certain goals, and keeps us interested in certain activities of Uno (2007).

\footnotetext{
* Corresponding author.

E-mail address: xxxx@xxxxxx.edu (First Author)
} 
Motivation is a concept that is expressed as a need (need), desire (want), encouragement (drive), or implus that can not be agreed with each other. Whereas Compensation is something that is received by employees, whether it consists of salaries, prizes, premiums, care, insurance and others that are paid directly by the company from Husein (2007). With the existence of three variables this study wants to know the effect on employee performance.

The word basic motivation is (motive) which means the impulse or stimulus that is in someone to do something. Thus motivation means a condition that encourages or stimulates someone to do an action or activity, which takes place consciously to achieve the goal company organization. According to Siagian (2004) Motivation is given as a driving force for employees to exert their abilities, expertise, skills.

Compensation is all forms of rewards received by workers in return for their work (Darsono \& Siswandoko, 2011).

According to Darsono \& Siswandoko (2011) Compensation is divided into several forms, namely:

1. Direct financial compensation

2. Indirect financial compensation

3. Non financial compensation,

According to Mangkunegara (2009) employee performance is the result of work in quality and quantity achieved by an employee in carrying out his duties in accordance with the responsibilities given to him.

\section{Methods}

\subsection{Types of research}

The data used in this study are primary data data obtained directly and carried out also for research conducted by employees of PT. Delami Brands Kharisma Busana Surabaya.

\subsection{Data source}

Primary data is the data obtained directly at the place where the research was conducted. In this study primary data sources will be obtained directly through questionnaires that have been shared and filled in by respondents in the form of a list of questions with the intention of knowing the response to employees of PT. Delami Brand Busana Surabaya.

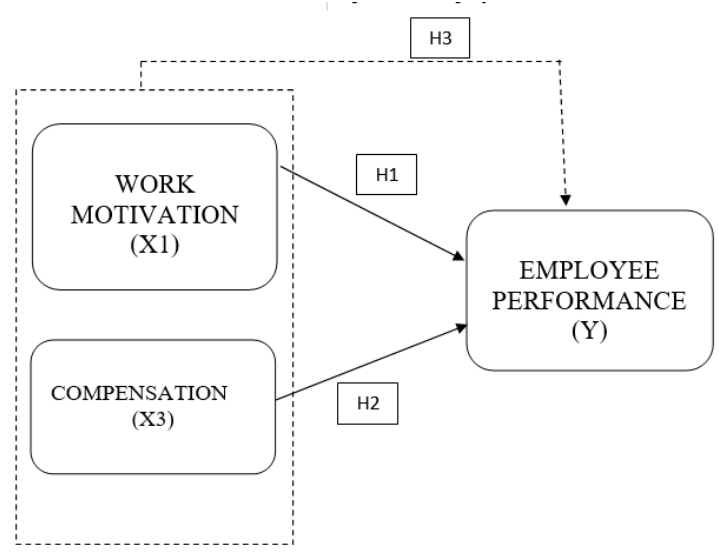

Fig. 1. Research framework

\subsection{Operational Definition of Research Variable}

\section{Work Motivation (X1)}

According to According to Wibowo (2011), motivation dimensions and indicators are as follows: 
1. The need for achievement:

2. Comprehensive needs of association

3. The need to master a job

\section{Compensation (X2)}

According to Simamora (2004), indicators for measuring compensation are given as follows:

1. Wages and salaries.

2. Incentives.

3. Benefits.

4. Facilities.

\section{Employee Performance (Y)}

Indicators to measure company performance individually there are six indicators, namely (Robbins, 1996):
1. Quality
2. Quantity
3. Timeliness
4. Effectiveness
5. Independence
6. Work Commitments

\subsection{Test Methods for Validity and Reliability}

Ghozali (2005) and Arianto (2013) a questionnaire to be valid if the question in the questionnaire is able to reveal something that will be measured by the questionnaire. An indicator is declared valid if $r$ has a significant level of less than 5\%. While according to reliability (Umar, 2000) is the accuracy, accuracy or accuracy shown by the measurement instrument. A question that has been asked valid in the validity test will be determined reliability by using the Cronbach alpha statistical test provided that the variable under study is declared reliable if the croanbach alpha value is above 0.6 .

\subsection{Multiple Regression Analysis}

This method is used to determine how much influence the independent variable (work motivation and compensation) has on the dependent variable (employee performance).

Multiple linear regression models used:

Where :

$$
\mathrm{Y}=a+\mathrm{b}_{1} \mathrm{X}_{1}+\mathrm{b}_{2} \mathrm{X}_{2}+\mathrm{e}
$$

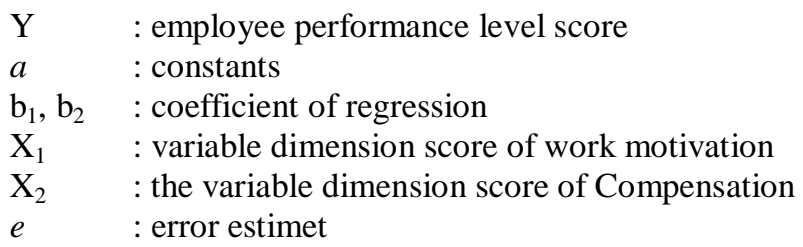

Source: Sugiono (2005)

\section{Result and Discussions}

\subsection{Reliability and Validity}

Based on the research shows that the cronbanch alpha value of work motivation is 0.720 , compensation is 0.720 , and 
employee performance is 0.720 , which means that it is above the acceptance limit of 0.6 . Based on the research value of the correlation index for the relationship between the independent variables (work motivation and compensation) and the dependent variable (employee performance) greater than 0.227 from the $r$ table and below the significant level of 0.05 , the results of the validity test of all items show results that positive, therefore, the data is considered valid.

\subsection{Results of Multiple Linear Regression}

\begin{tabular}{|c|c|c|c|c|c|c|}
\hline \multicolumn{7}{|c|}{ Coefficients $^{\mathrm{a}}$} \\
\hline \multirow{2}{*}{\multicolumn{2}{|c|}{ Model }} & \multicolumn{2}{|c|}{ Unstandardized Coefficients } & $\begin{array}{l}\text { Standardized } \\
\text { Coefficients }\end{array}$ & \multirow[b]{2}{*}{$\mathrm{t}$} & \multirow[b]{2}{*}{ Sig. } \\
\hline & & B & Std. Error & Beta & & \\
\hline 1 & (Constant) & 8.992 & 1.371 & & 6.559 & 0.000 \\
\hline & $\begin{array}{l}\text { Work_Motivation } \\
\text { X1 }\end{array}$ & 0.482 & 0.057 & 0.622 & 8.433 & 0.000 \\
\hline & $\begin{array}{l}\text { Compensation } \\
\mathrm{X} 2\end{array}$ & 0.201 & 0.044 & 0.337 & 4.564 & 0.000 \\
\hline
\end{tabular}

a. Dependent Variable: Employee_Performance

$$
\mathrm{Y}=8.992+0.482 \mathrm{X}_{1}+0.201 \mathrm{X}_{2}+\mathrm{e}
$$

The equation of linear regression means:

a. The constant $(\alpha)$ of 8.992 shows that if there is an influence of independent variables $\left(\mathrm{X}_{1}, \mathrm{X}_{2}\right)$ in the form of Work Motivation variables, and Compensation, then the employee's performance will remain at 8.992.

b. Work Motivation regression coefficient $\left(b_{1}\right)$ has a positive value of 0.482 , this means that if Work Motivation increases by one unit it will increase the performance by 0.482 units.

c. Compensation regression coefficient $\left(b_{2}\right)$ has a positive value of 0.201 , this means that if Compensation increases by one unit it will increase performance by 0.201 units.

\subsection{Results from $R$ Square}

From the results of calculations using the SPSS version 18 program, it can be seen that the value of $\mathrm{R}$ Square $=0.660$ shows the magnitude of the influence of Work Motivation variable $\left(\mathrm{X}_{1}\right)$, Compensation $\left(\mathrm{X}_{2}\right)$, and Employee Performance (Y) of $66.0 \%$. Means that there are still influences of other variables of $3.4 \%$ that affect work performance but not examined in this study.

\begin{tabular}{|l|r|r|r|r|r|}
\hline Model Summary & \\
\hline Model & \multicolumn{1}{|c|}{$\mathrm{R}$} & R Square & Adjusted R Square & $\begin{array}{c}\text { Std. Error of the } \\
\text { Estimate }\end{array}$ & Durbin-Watson \\
\hline 1 & $0.812^{\mathrm{a}}$ & 0.660 & 0.651 & 1.29227 & 1.814 \\
\hline
\end{tabular}

a. Predictors: (Constant), Work_Motivation, Compensation

b. Dependent Variable: Employee_Performance 


\subsection{Classical Assumptions Test}

\subsubsection{Multicollinearity Results}

\section{Coefficients $^{\mathrm{a}}$}

\begin{tabular}{|l|c|c|}
\hline \multirow{2}{*}{\multicolumn{1}{|c|}{ Model }} & \multicolumn{2}{|c|}{ Collinearity Statistics } \\
\cline { 2 - 3 } & Tolerance & VIF \\
\hline Work_Motivation & 0.855 & 1.169 \\
\hline Compensation & 0.855 & 1.169 \\
\hline
\end{tabular}

Based on muticollinearity result, it can be explained that the questionnaire research data used can be used for further testing because of the results of this multicollinearity test, the research data has a VIF value of $<10$ and a tolerance value of less than 1 .

\subsubsection{Heterocedasticity test}

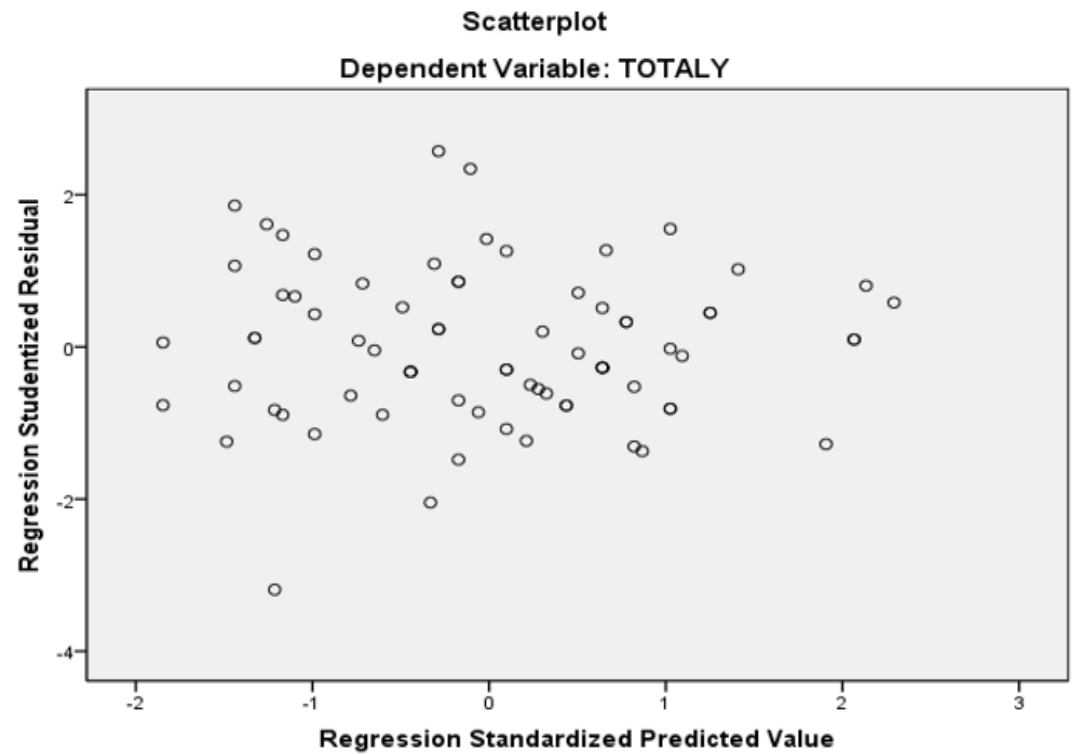

Based on the results of heteroscedasticity test shown in the picture above that there is no clear pattern and the points spread above and below the zero on the Y axis. independent or independent variable namely Work Motivation and Compensation.

\subsection{3. $T$ test}

To interpret the results of the hypothesis from the analysis, it can be explained as follows:

a. $\mathrm{T}_{\text {count }}$ value $8,433<\mathrm{T}_{\text {table }} 1,993$. So that it can be concluded that Ho is accepted and Ha is rejected means that there is no significant negative effect $\mathrm{X}_{1}$ on $\mathrm{Y}$.

b. $\mathrm{T}_{\text {count }}$ value 4,564 $<\mathrm{T}_{\text {table }} 1,993$. So that it can be concluded that Ho is accepted and Ha is rejected means that there is no significant negative effect of $\mathrm{X}_{2}$ on $\mathrm{Y}$. 


\begin{tabular}{|c|c|c|c|c|c|c|}
\hline \multicolumn{7}{|c|}{ Coefficients $^{\mathrm{a}}$} \\
\hline \multirow{2}{*}{\multicolumn{2}{|c|}{ Model }} & \multicolumn{2}{|c|}{ Unstandardized Coefficients } & \multirow{2}{*}{$\begin{array}{c}\begin{array}{c}\text { Standardized } \\
\text { Coefficients }\end{array} \\
\text { Beta }\end{array}$} & \multirow[b]{2}{*}{$\mathrm{t}$} & \multirow[b]{2}{*}{ Sig. } \\
\hline & & B & Std. Error & & & \\
\hline \multirow[t]{3}{*}{1} & (Constant) & 8.992 & 1.371 & & 6.559 & 0.000 \\
\hline & $\begin{array}{l}\text { Work_Motivation } \\
\text { X1 }\end{array}$ & 0.482 & 0.057 & 0.622 & 8.433 & 0.000 \\
\hline & $\begin{array}{l}\text { Compensation } \\
\mathrm{X} 2\end{array}$ & 0.201 & 0.044 & 0.337 & 4.564 & 0.000 \\
\hline
\end{tabular}

a. Dependent Variable: Employee_Performance

\subsubsection{F test}

Because the probability of synergy is much smaller than sig $<0.05$, then the regression model can be used to predict the performance of employees of PT.Delami Brands Kharisma Busana Surabaya, or it can be said that Work Motivation $\left(\mathrm{X}_{1}\right)$, Compensation $\left(\mathrm{X}_{2}\right)$, are jointly influential on the performance of employees of PT. Delami Brands Kharisma Busana Surabaya.

ANOVA $^{b}$

\begin{tabular}{|ll|r|r|r|r|r|}
\hline Model & & Sum of Squares & df & Mean Square & F & Sig. \\
\hline 1 & Regression & 236.725 & 2 & 118.362 & 70.878 & $0.000^{\mathrm{a}}$ \\
& Residual & 121.907 & 73 & 1.670 & & \\
& Total & 358.632 & 75 & & & \\
\hline
\end{tabular}

a. Predictors: (Constant), Motivation_Work, Compensation

b. Dependent Variable: Employee_Performance

\subsection{Discussion}

\subsubsection{Effect of Work Motivation on Employee Performance}

The first hypothesis proposed states that Work Motivation significantly influences employee performance, partially this has been proven by the results of $t$ test value 8.433. This is rational because it is in accordance with the responses of respondents regarding Work Motivation. In response, respondents stated that Work Motivation given by the company was in accordance with their wishes. Significant influence of Work Motivation on Employee performance can be clarified by the results of multiple linear regression analysis. Multiple linear regression analysis also indicates that every increase in one Work Motivation unit, the performance will also increase by 0.622 . Means the higher / greater Work Motivation, the better / higher employee performance.

\subsubsection{Effect of Compensation on Employee Performance}

The first hypothesis proposed states that Compensation has a significant effect on employee performance, partially this has been proven by the results of $t$ test value 4.564. This is rational because it is in accordance with the respondent's response regarding compensation. In his response the respondents stated that the compensation given by the company was in accordance with their expectations and needs. The significant effect of Compensation on Employee performance can be clarified by the results of multiple linear regression analysis. Multiple linear regression analysis also indicates that for each increase in one Compensation unit the performance will also increase by 0.337 . Means that the higher / greater Compensation, the better / higher the employee's performance. 


\subsubsection{Effect of Work Motivation and Compensation on Employee Performance}

The third hypothesis states that Work Motivation and Compensation have a significant effect on Employee performance. This is evident from the results of the questionnaire, respondents stated that the company has provided adequate Work Motivation and Compensation for them. Based on the F test, it can be seen that Work Motivation and Compensation together have a positive and significant effect on improving employee performance. This is seen from the value of $\mathrm{f}_{\text {count }}>\mathrm{f}_{\text {table, }}$, which is $70.878>2.92$, which means that the better the Work Motivation and Compensation simultaneously, the better the Employee Performance. Simultaneous influence is also strengthened by the results of the coefficient of determination (value of R Square), this is to find out how much influence the independent variables have on the dependent variable. It can be seen that the R Square value of 0.660 shows that the magnitude of the influence of the variable Work Motivation and Compensation on Employee Performance is $66.0 \%$.

\section{Conclusions}

Based on the results of the research and analysis that has been carried out, it can be found several things which are the conclusions of this study, namely:

a) Work Motivation has a positive and significant effect on Employee Performance, this means that if Work Motivation increases it will improve Employee Performance.

b) Compensation has a positive and significant effect on Employee Performance, this means that if Compensation increases it will improve Employee Performance

c) Together the two independent variables consisting of Work Motivation (X1), and Compensation (X2), have a positive and significant effect on Employee Performance (Y). This means that if Work Motivation and Compensation increase together it will improve Employee Performance.

\section{References}

Arianto, D. A. N. (2013). Pengaruh kedisiplinan, lingkungan kerja dan budaya kerja terhadap kinerja tenaga pengajar. Jurnal Economia, 9(2), 191-200.

Darsono \& Siswandoko T. (2011). Manajemen sumber daya manusia abad 21. Jakarta: Nusantara Consulting.

Ghozali, I. (2005). Analisis Multivariate dengan program SPSS. Semarang: Badan Penerbit Universitas Diponegoro.

Husein, U. (2007). Metode Penelitian Untuk Skripsi dan Tesis Bisnis. Jakarta: PT. Raja Grafindo Persada.

Mangkunegara, A. P., \& Prabu, A. (2009). Manajemen sumber daya manusia. Bandung: PT. Remaja Rosdakarya.

Robbins, S. P. (1996). Perilaku Organisasi, Konsep, Kontroversi dan Aplikasi (Edisi Keenam). Jakarta: PT Bhuana Ilmu Popular.

Siagian, S. P. (2004). Kiat meningkatkan produktivitas kerja. Jakarta: Rineka Cipta.

Simamora, H. 2004. Manajemen Sumber Daya Manusia. $3^{\text {rd }}$ Edition. Yogyakarta: Sekolah Tinggi Ilmu Ekonomi $Y K P N$.

Sugiyono. 2005. Metode Penelitian Bisnis. Bandung: Alfabeta.

Uno, H. B. (2007). Teori motivasi dan pengukuran. Jakarta: Bumi Aksara.

Wibowo. 2011. Manajemen Kinerja. Jakarta: PT. Rajagrafindo Persada. 